quinidine depression. Consequently, depletion of catecholamines by reserpine would permit quinidine depression to develop more readily. It may also be argued that reserpine, like quinidine, is a cardiac depressant? and that against a background of reserpine-induced depression, the effect of quinidine would be enhanced. However, a direct depressant action by reserpine seems unlikely since the rate and stability of isolated reserpinized hearts did not differ from those of non-reserpinized preparations ${ }^{8}$. Furthermore, unlike quinidine, reserpine pretreatment does not affect the rate of rise or the overshoot of atrial action potentials ${ }^{9}$.

This work was supported by a grant from the National Heart Institute, U.S. National Institutes of Health.

ERIK NyE

JAY ROBERTS

Department of Pharmacology,

Cornell University Medical College, New York.

${ }^{1}$ Mancini, M. A., and Graubner, W., Boll. Soc. Ital. Biol., 15, 389 (1940).

${ }^{2}$ Roberts, J., and Baer, R., J, Pharmacol., 129, 36 (1960).

s Dresel, P. E., Hurt, M. C., and Strömblad, B. C. R., J. Pharmacol.,140, 67 (1963).

- Krebs, H. A., and Henseleit, K., Hoppe-Seyl. Z., 210, 33 (1932).

Grumbach, L., Circulation Res., 4, 112 (1956).

- Roberts, J., Stadter, R. P., Cairoli, V., and Modell, W., Circulation Res., 11, $758(1962)$.

'Boyajy, L. D., and Nash, C. B., J. Pharmacol., 148, 193 (1965).

${ }^{8}$ Roberts, J., Ehrreich, S., and Levitt, B., Fed. Proc., 24, 1421 (1965).

- Vaughan Williams, E. M., J. Physiol., 140, 21 (1958).

\section{Tumour-inducing Effect of Hydrazine in Mice}

After the discovery of the experimental tumourinducing effect of isonicotinic acid hydrazide ${ }^{1}$ several later investigations verified that this compound showed carcinogenic effects in white mice of different inbred strains when administered intraperitoneally or orally over a long period ${ }^{2-8}$. According to Mori et al. ${ }^{9}$, the carbamyl group is responsible for the cancerogenic effect of isonicotinic acid hydrazide. On the other hand, Biancifiori et $a l^{3}$ are of the opinion that the hydrazine radical ${ }^{10}$ detached from the compound during the metabolic process plays a part in producing tumours. They found in their experiments that the frequency of tumours in mice of $B A L B / c$ strain caused by isonicotinic acid hydrazide or hydrazine sulphate was very high, while isonicotinic acid alone showed no carcinogenic effect.

In our own experiments we administered hydrazine to white mice having an average weight of $20 \mathrm{~g}$. Hydrazine $\left(\mathrm{NH}_{2}-\mathrm{NH}_{2}\right)$ is easily soluble in alcohol and water. It is a bivalent weak base; in a watery solution mono- or bivalent mono- or dihydrate develops. Each injection contained $0.5 \mathrm{mg}$ hydrazine in a $0.5 \mathrm{ml}$. physiological saline solution. We treated thirty male and thirty female mice intraperitoneally, at the beginning of the experiment on each second day, and later on each third day. 16 injections were given in all over a period of 46 days. Altogether, $400 \mathrm{mg} / \mathrm{kg}$ body weight of hydrazine entered the organism of the experimental anmals.

Treatment with hydrazine caused the development of focal liver necroses in some of the animals; twenty-six animals died as a result of severe liver damage in the first period of the experiment. The liver-damaging effect of drugs containing the hydrazine radical is a well-known elinical phenomenon ${ }^{11-13}$. Thirteen of the thirty-four mice surviving the treatment developed tumours and myeloid leukaemias between days 100 and 313 reckoned from the beginning of the experiment. The tumours appeared in the mediastinum and showed a local invasion, sometimes provoking metastases in the lungs, pleura and liver. Histologically the tumours proved to be reticular-cell sarcomata. In tho cases of myeloid leukaemia, enlargement of the liver, spleen and lymph nodes was to be seen; histologically, there was infiltration of these organs as well as of the bone marrow by immature myeloid cells. As controls, we used sixty white mice of the same pedigree and age; there was only one case of spontaneous thymic lymphoma in them during a year's observation.

The hepatotoxic effect of hydrazine has been known for some time, but there were no communications on its eancerogenic effect. The investigations carried out with isonicotinic acid hydrazide directed attention to this property of hydrazine. The further examination of this compound, which has a very simple chemical structure, may reveal other valuable results. The question is of interest also from the point of view of human pathology, since many other drugs also contain hydrazine radicals, which may liberate hydrazine in the course of metabolism. Thus, a thorough investigation of hydrazine may also give us information about the important question of the cancerogenic effect of drugs.

$$
\begin{aligned}
& \text { J. JuHÁsz } \\
& \text { J. BALó } \\
& \text { B. Szende }
\end{aligned}
$$

First Department of Pathological Anatomy and Experimental Cancer Research, Medical University, Budapest.

1 Juhász, J., Baló, J., and Kendrey, G., Z. Krebsforsch., 62, 188 (1957).

${ }^{2}$ Mori, K., and Yasuno, A., Gann, 50, 107 (1959).

${ }^{3}$ Biancifiori, C., and Ribacchi, R., Nature, 194, 488 (1962).

${ }^{4}$ Biancifiori, C., Bucciarelli, E., Clayson, D. B., and Santilli, F. E., Brit. $J$. Cancer, 18, 543 (1964).

${ }^{5}$ Schwan, S., Patol. Polska, 13, 185 (1962).

- Juhász, J., Baló, J., and Szende, B., Z. Krebsforsch., 65, 434 (1963).

${ }^{2}$ Ribacchi, R., Biancifiori, C. Milia, U., Di Leo, F. P., and Bucciarelli, k.. Lav. Anat. Pat. Perugia, 23, 103 (1963).
Libacchi, R., Bianciori, C., Milia, U, Di

${ }^{8}$ Weinstein, H. J., and Kinosita, R., Amer. Rev. Respirat. Dis., 88, 124 (1963).

${ }^{9}$ Mori, K., Yasuno, A., and Matsumoto, K., Gann, 51, 83 (1960).

${ }^{10}$ Krüger-Thiemer, E., Amer. Rev. Tubercul., 77, 364 (1958).

${ }^{11}$ Alexander, H. S., Reactions with Drug Therapy (W. B. Saunders Co.. Philadelphia and London, 1955).

${ }^{2}$ Shay, H., and Sun, D. C. H., Ann. Intern. Med., 49, 1246 (1958).

${ }^{13}$ Beer, D. T., and Sehaffner, F., J. Amer. Med. Assoc., 171, 887 (1959).

\section{Effects of 3,4-Dimethoxyphenylethylamine in Man}

Four laboratories have reported finding 3,4-dimethoxyphenylethylamine (DMPEA) in the urine of schizophrenic patients ${ }^{1-4}$. Evidence for its occurrence in some patients with this disorder seems well established despite a single negative report ${ }^{5}$. As the compound is quite closely related chemically to mescaline, the latter possessing an additional methoxy-group in the 5-position, it is conceivable that DMPEA might have similar activity in humans.

In initial attempts to determine activity in man, conservative oral doses of the free amine were used, beginning with $50 \mathrm{mg}$ and increasing to a dose of 600 $\mathrm{mg}$, without any appreciable clinical effects being noted. Because of the possibility that the free amine might not be absorbed, a bitartrate salt was prepared, and adminis. tered in similar fashion with similar lack of effect at doses up to $800 \mathrm{mg}$. A similar testing procedure was followed with the hydrochloride salt and then a formal investigation was contrived to compare DMPEA with mescaline and placebo under blind controlled conditions.

Thirteen volunteer subjects were studied. Twelve were recovered psychiatric patients, seven with previous diagnoses of schizophrenic reaction, three with depressive reactions and two with psychoneuroses; the other volunteer had no history of emotional disorder. Three trials were conducted at weekly intervals. In the first trial, DMPEA was given on each occasion, nine of the subjects receiving doses of $500 \mathrm{mg}$, the last three receiving doses of $1,000 \mathrm{mg}$. Mescaline and placebo were administered in random order over the next two trials; the dose of mescaline was based on $6 \mathrm{mg} / \mathrm{kg}$, the actual ranges being $40 \tilde{5}_{-}$ 